\title{
Rectal Micropapillary Adenocarcinoma
}

National Cancer Institute

\section{Source}

National Cancer Institute. Rectal Micropapillary Adenocarcinoma. NCI Thesaurus. Code C96493.

A rare, invasive rectal adenocarcinoma characterized by the presence of clusters of malignant glandular cells within stromal spaces. 